\title{
PENGARUH BLENDED LEARNING TERHADAP HASIL BELAJAR MAHASISWA KEBIDANAN STIKES PEMKAB JOMBANG
}

\section{THE EFFECT OF BLENDED LEARNING ON THE LEARNING OUTCOMES OF MIDWIFERY STUDENTS STIKES PEMKAB JOMBANG}

\author{
Chanda Paramitha Bherty ${ }^{1}$, Rosa Purwanti ${ }^{2}$, Dwi Sri Rahandayani ${ }^{3}$, Erika Agung Mulyaningsih ${ }^{4}$ \\ ${ }^{1}$ Stikes Pemkab Jombang
}

Riwayat artikel

Diajukan: Agustus 2021

Diterima: September 2021.

\section{PenulisKorespondensi:}

- Chanda Paramitha Bherty

- Stikes Pemkab Jombang

- bhertychanda@yahoo.c o.id

Kata Kunci:

Blended Learning, Hasil Belajar

\begin{abstract}
Abstrak
Blended Learning merupakan metode pembelajaran yang menggabungkan antara pembelajaran online dan juga pembelajaran offline (face to face). Di masa pandemic pembelajaran untuk mahasiswa kebidanan diharapkan dapat dimodifikasi untuk tetap menghasilkan lulusan yang kompeten. Blended Learning dapat menjadi solusi pelaksanaan pembelajaran pada masa pandemic khususnya bagi mahasiswa kebidanan. Penelitian ini menggunakan desain analitik observasional dengan pendekatan kohort prospektif. Populasi pada penelitian ini adalah mahasiswa kebidanan Stikes Pemkab Jombang Semester II. Teknik sampel menggunakan purposive sampling dengan 13 orang sampel kasus dan 13 orang kontrol. Variabel pada penelitian ini adalah pembelajaran Blended Learning dan Hasil Belajar. Uji statistik yang digunakan adalah uji Independent $T$. Test . Berdasarkan hasil uji Independent T.Test mendapatkan hasil significant $0.022<0.05$. dapat disimpulkan bahwa terdapat pengaruh Blended Learning terhadap Hasil Belajar pada mahasiswa kebidanan Stikes Pemkab Jombang.
\end{abstract}

\begin{abstract}
Blended Learning is a learning method that combines online learning and offline learning (face to face). During the pandemic, learning for midwifery students is expected to be modified to continue to produce competent graduates. Blended Learning can be a solution for implementing learning during a pandemic, especially for midwifery students. This study uses an observational analytic design with a prospective cohort approach. With the respondents of midwifery students, the Jombang regency government sticks. The sampling technique used purposive sampling with 13 case samples and 13 control samples. The variables in this study are Blended Learning and Learning Outcomes. The statistical test used is the Independent T. Test. Based on the results of the Independent T.Test test, the significant results were $0.022<0.05$. It can be concluded that there is an effect of Blended Learning on Learning Outcomes in midwifery students of Stikes Pemkab Jombang.
\end{abstract}




\section{Pendahuluan}

Pada akhir tahun 2019 dunia Kesehatan dikejutkan dengan keberadaan suatu varian virus baru bernama Corona. Penyakit tersebut bernama Corona Virus Desease- 19 (COVID-19), Virus ini pertama kali ditemukan di negara Cina tepatnya di kota Wuhan. Corona yang semula dianggap virus biasa ternyata virus ini dapat membunuh manusia sekaligus menyebar sangat cepat. Gejala yang muncul menyerupai flu, masuk angin, batuk, dan demam. Negara-negara didunia memberlakukan Kebijakan pembatasan akses fisik ke layanan publik seperti pusat perbelanjaan, rumah ibadah, kantor maupun sekolah (melia, A., 2020).

Menurut Worldometers Data penderita Covid-19 di dunia pada tanggal 25 Juni 2021 pukul 06.00 adalah sebanyak 180.729 .556 orang didunia terinfeksi virus Covid-19 dan 2.915.122 orang meninggal dunia. Sedangkan di Indonesia sendiri yang sebelumnya kasus penderita Covid-19 sempat menurun dengan adanya gencarnya pemerintah melakukan program vaksinasi. Jumlah sasaran vaksinasi di Indonesia adalah 181.554.465 dengan rincian jumlah 23.789.884 orang sudah tervaksinasi dosis I dan 12.514.917 orang tervaksinasi dosis II data tersebut diambil dari web resmi https://covid19.go.id, dengan tingginya jumlah masyarakat yang sudah tervaksin ternyata tidak berbanding lurus dengan jumlah penderita Covid-19 yang menurun. Indonesia kembali pecah rekor penderita Covid-19 pertanggal 25 Juni 2021 pukul 12.00 jumlah penambahan kasus terkonfirmasi positif di Indonesia bertambah 20.574 orang sehingga total kasus Covid-19 di Indonesia berjumlah 2.053 .995 orang.

Hadirnya pandemi corona membawa dampak seluruh aspek kehidupan, termasuk dalam bidang pendidikan. Pendidikan mengalami transformasi yang fundamental dalam berbagai komponen pendidikan. Pemerintah memberlakukan kebijakan bahwa seluruh Proses Pembelajaran dilaksanakan secara daring atau Study From Home (SFH) dari jenjang Pendidikan PAUD sampai dengan Perguruan Tinggi. Raw input pendidikan yang akan di olah melalui proses pendidikan mengalami pergeseran proses dan orientasi. Pendidik yang seakan sudah nyaman dan mapan dalam memainkan perannya sebagai aktor pendidikan harus di paksa mengikuti tuntutan kebutuhan dan kondisi implementasi pendidikan. Kurikulum yang baru saja diimplementasikan dipaksa harus menyesuaikan tuntutan perubahan tujuan, materi, metode dan model penilainnya. Strategi pembelajaran yang telah didesain dengan sintaks yang sangat prosedural sistematis harus mengalami perubahan adaptif yang mengarah pada pergeseran paradigma pembelajaran. Sistem penilaian lebih banyak mengarah pada penilai otentik berbasis pada pengalaman peserta didik. Pengelolaan pendidikan lebih banyak dilakukan melalui model daring, dengan mengikuti digitalisasi dalam pendidikan. Peran lembaga pendidikan bergeser dari dominasi pendidikan model persekolahan kearah pendidikan partisipatif yang melibatkan keluarga atau orang tua dalam implementasi pendidikan. Kondisi demikian menodorong terjadinya perubahan pola pikir pendidik, peserta didik dan pengelola lembaga pendidikan yang berdampak pada pengelolaan pembelajaran (Herwin, dkk.,2020)

Pembelajaran jarak jauh (distance learning) merupakan metode pembelajaran yang cepat berkembang seiring dengan berkembangnya teknologi internet. Pembelajaran jarak jauh dilakukan dengan pendekatan substitusi dari pembelajaran tatap muka secara konvensional. Belajar secara daring tentu bukan hal yang mudah bagi mahasiswa khususnya mahasiswa Pendidikan Kebidanan. Kesulitan utama adalah bagaimana mahasiswa kebidanan dituntut harus kompeten terhadap Skillnya yang berhubungan dengan Kesehatan Ibu dan Anak. Dengan keterampilan yang kurang kompeten bukan tidak mungkin angka kematian ibu dan bayi meningkat dan menjadi permasalahan baru di dunia Kesehatan (Hasriani, 2020). 
Dengan adanya tuntutan lulusan kebidanan harus kompeten Institusi Kesehatan khususnya kebidananan diharapkan mampu mengembangkan metode pembelajaran dan memikirkan metode pembelajaran yang baik permasalahan baru di dunia Kesehatan (Hasriani, 2020).

Pada masa pandemic Covid-19 ini. Menurut Surat Keputusan 4 Menteri pada bulan Agustus 2020 mengatakan bahwa proses pembelajaran dapat dilakukan dengan metode Blended Learning, yaitu metode pembelajaran yang menggabungkan berbagai cara penyampaian, model pengajaran, dan gaya pembelajaran, memperkenalkan berbagai pilihan media dialog antara fasilitator dengan orang yang mendapat pengajaran. Blended learning juga sebagai sebuah kombinasi pengajaran langsung (face-to-face) dan pengajaran online, tapi lebih daripada itu sebagai elemen dari interaksi social. Blended Learning dinilai dapat menjadi solusi mencapai kompetensi kebidanan dengan tetap melakukan praktik laboratorium di kampus dan juga praktik klinik di Fasilitas Kesehatan yang sesuai dengan kompetensi mahasiswa.

Adanya fenomena tersebut peneliti ingin melakukan penelitian tentang pengaruh pelaksanaan blended learning terhadap hasil belajar mahasiswa prodi DIII Kebidanan dan Sarjana Kebidanan Stikes Pemkab Jombang.

\section{Metode Penelitian}

Desain penelitian ini menggunakan desain analitik observasional dengan pendekatan kohort prospektif. Populasi penelitian adalah semua mahasiswa prodi DIII Kebidanan dan S1 Kebidanan. Teknik sampling, yang digunakan dalam penelitian ini adalah non probability sampling dengan jenis Purposive Sampling dengan jumlah sampel 13 orang sampel kasus yaitu mahasiswa Program Studi D III Kebidanan dan 13 orang kontrol dari Mahasiswa Program Studi Sarjana Kebidanan.

Variabel pada penelitian ini adalah Pembelajaran Blended Learning sebagai variable Bebas dan hasil belajar sebagai variable terikat. Instrumen yang digunakan dalam penelitian ini adalah data sekunder yaitu nilai Indeks Prestasi Kumulatif semester II. Terdapat analisis data univariate dan bivariate dalam penelitian ini, untuk menguji statistic kedua variable menggunakan uji Independent T.Test.

\section{Hasil dan Pembahasan \\ Data Umum}

Tabel 4.1 Tabel distribusi Responden Berdasarkan Usia mahasiswa Prodi Kebidanan Stikes Pemkab Jombang

\begin{tabular}{ccccc}
\hline Usia & \multicolumn{2}{c}{ Kasus } & \multicolumn{2}{c}{ Kontrol } \\
& n & \% & n & \% \\
\hline 15-18 tahun & 3 & 23.1 & 1 & 7.7 \\
19-21 ahun & 10 & 76.9 & 11 & 84.6 \\
>21 tahun & 0 & 0 & 1 & 7.7 \\
Jumlah & 13 & 100 & 13 & 100 \\
\hline
\end{tabular}

Sumber : Data Primer Tahun 2021

Berdasarkan table 4.1 dapat dilihat pada responden kasus sebagian besar $76,9 \%$ berusia 19 s/d 21 tahun, sedangkan pada responden control sebagian besar $84.6 \%$ berusia $19 \mathrm{~s} / \mathrm{d} 21$ tahun.

\section{Data Khusus}

a. Metode Pembelajaran

Tabel 4.3 Tabel distribusi Responden Berdasarkan metode Pembelajaran yang diberikan

\begin{tabular}{ccc}
\hline Responden & $\begin{array}{c}\text { Metode } \\
\text { Pembelajaran }\end{array}$ & Jumlah \\
\hline Kasus & Blended & 13 \\
& Learning & 13 \\
Kontrol & Full Online & 26 \\
\hline
\end{tabular}

Sumber : Data Primer Tahun 2021

Berdasarkan table 4.3 dapat dilihat bahwa pada kelompok kasus sebanyak 13 orang yang mendapat pembelajaran Blended Learning dan pada kelompok kontrol sebanyak 13 orang yang mendapat pembelajaran dengan full Online. 
b. Hasil Belajar

Table 4.4 distribusi hasil belajar mahasiswa pada responden kasus dan control.

\begin{tabular}{lcccc}
\hline Hasil Belajar & \multicolumn{4}{c}{ Responden } \\
\cline { 2 - 5 } & \multicolumn{3}{c}{ Kasus } & \multicolumn{2}{c}{ Kontrol } \\
\cline { 2 - 5 } & Jumla & $\mathbf{( \% )}$ & Jumla & (\%) \\
& h & & h & \\
\hline Cumlaude & 11 & 84. & 7 & 53. \\
& & 6 & & 8 \\
\hline Sangat & 2 & 15. & 4 & 30. \\
memuaska & & 4 & & 8 \\
n & & & & \\
\hline $\begin{array}{l}\text { Memuaska } \\
\text { n }\end{array}$ & 0 & 100 & 2 & 100 \\
\hline
\end{tabular}

Sumber: Data Primer tahun 2021

Berdasarkan tabel 4.4 mahasiswa yang mendapatkan hasil belajar dengan predikat cumlaude adalah $84.6 \%$ (sebagian besar) pada kelompok kasus dan $53.8 \%$ (lebih dari setengahnya) pada kelompok kontrol.

\section{Analisis Bivariate pengaruh Blended Learning terhadap Hasil Belajar pada Mahasiswa Prodi DIII Kebidanan dan Sarjana Kebidanan}

Berdasarkan uji Independent $\mathrm{T}$. Test mendapatkan hasil significan $0.022<0.05$. dapat disimpulkan bahwa terdapat pengaruh Blended Learning terhadap Hasil Belajar pada Mahasiswa Prodi DIII Kebidanan dan Sarjana Kebidanan.

\section{Simpulan}

Berdasarkan hasil penelitian pada table 4.4 diketahui bahwa sebesar 53,8\% mahasiswa pada kelompok kontrol yang hanya menerima pembelajaran secara online mencapai hasil belajar dengan predikat cumlaude, sedangkan pada kelompok kasus sebesar 84,6\% yang mendapatkan pembelajaran secara blended learning mencapai hasil belajar dengan predikat cumlaude. Perbedaan pencapaian hasil belajar ini dapat disebabkan beberapa hal diantaranya keterbatasan system pembelajaran yang dilakukan secara online dengan kendala utama yang paling banyak dialami mahasiswa adalah ketersediaan jaringan di tempat tinggal masing-masing mahasiswa, sehingga materi yang disampaikan oleh dosen kurang dapat diterima dengan baik.

Pengetahuan adalah segala sesuatu yang diketahui, kepandaian dan segala sesuatu yang diketahui berdasarkan sesuatu (mata kuliah). Selain itu, pengetahuan dapat didefinisikan hasil dari tahu dan terjadi setelah orang melakukan penginderaan terhadap objek tertentu. Sebagian besar manusia memperoleh pengetahuan melalui penginderaan yaitu mata dan telinga. Oleh karena itu, pengetahuan merupakan suatu informasi atau fakta yang diperoleh dari proses belajar dan pengalaman. Seseorang yang memiliki pengetahuan dapat bertindak atau menyelesaikan masalah yang dihadapi. Pengetahuan atau kognitif merupakan domain yang sangat penting daam membentuk tindakan seseorang (over behaviour). (Prapitasari, 2020)

Keterbatasan dalam pelaksanaan pemebelajaran jarak jauh dalam jaringan (daring) dapat menyebabkan pengetahuan mahasiswa menjadi kurang sehingga berpengaruh terhadap pencapaian hasil belajar mahasiswa. Selain pengetahuan yang kurang hasil belajar mahasiswa juga sangat dipengaruhi oleh motivasi belajar mahasiswa. Mahasiswa yang memiliki motivasi belajar yang baik akan mempunyai pengetahuan yang baik pula.

Evaluasi hasil belajar melalui nilai Indeks Prestasi Kumulatif (IPK) merupakan salah satu standar yang dapat digunakan sebagai tolak ukur keberhasilan mahasiswa dalam menempuh suatu pendidikan di perguruan tinggi. Faktor lain yang dapat mempengaruhi hasil belajar terdiri dari faktor eksternal dan internal. Faktor internal diantaranya yaitu kesiapan dalam menghadapi perkuliahan, motivasi, cara belajar, kesehatan dan tingkat intelegensi seseorang. Factor eksternal yang mempengarhu hasil belajar diantaranya adalah keluarga, masyarakat, dan lingkungan sekitar (Arikunto, 2012), termasuk dalam factor eksternal di masa pandemic ini adalah ketersediaan jaringan di 
wilayah tempat tinggal masing-masing mahasiswa.

Hasil penelitian menunjukkan bahwa berdasarkan uji Independent T. Test didapatkan hasil significan yaitu $0.022<$ 0.05. hasil uji statistic ini dapat disimpulkan bahwa terdapat pengaruh blended learning terhadap hasil belajar mahasiswa pada kelompok kontrol dan kelompok kasus. Metode pembelajaran blended learning yang diterapkan pada kelompok kasus hasil belajar yang dicapai mahasiswa lebih baik dibanding dengan kelompok kontrol yang hanya menerima perkuliahan online secara penuh. Hasil penelitian ini sejalan dengan penelitian yang dilakukan (Istiqomah, 2013) yang menyimpulkan bahwa Penerapan metode pembelajaran blended learning berbasis ICT pada mata kuliah Ilmu Sosial Budaya Dasar (ISBD) secara tepat dapat meningkatkan minat dan prestasi belajar. Blended learning merupakan suatu pendekatan pembelajaran yang memadukan antara kegiatan perkuliahan tatap muka (inclass session) dengan pembelajaran secara online sebagai upaya untuk menggabungkan keunggulan dari kedua jenis metode yang digunakan (Jesse, 2012; Vaughan et al, 2013 dalam (Istiqomah, 2013)

Perubahan metode pembelajaran konvensional menjadi pembelajaran daring merupakan tantangan bagi dosen. Dosen sebagai tenaga pendidik menurut UU RI No. 14 Tahun 2005 dituntut memiliki tugas keprofesionalan dalam mengembangkan kompetensi pengajaran dengan perkembangan IPTEK terkini dalam melaksanakan pembelajaran di kelas dan mengembangkan sesuai dengan kebutuhan (Nomor, Dosen, \& Saat, 2021). Blended learning adalah sebuah kemudahan pembelajaran yang menggabungkan berbagai cara penyampaian, model pengajaran, dan gaya pembelajara, memperkenalkan berbagai pemilihan media dialog antara fasilitator dengan orang yang mendapat pengajaran. Blended learning juga sebuah kombinasi pengajaran secara langsung (face to face) dan pengajaran online (Hidayah, 2020). Metode pembelajaran blended learning di masa pandemi Covid-19 pada program studi kebidanan dinilai cukup sesuai karena satu sisi di masa pandemi harus membatasi interaksi social, namun di sisi lain ketrampilan di dapat dengan melakukan proses pembelajaran di laboratorium dan klinik yang dilakukan secara terbatas dan dengan menerapkan protocol kesehatan yang ketat.

\section{Daftar Pustaka}

Amalia, A. Sa'adah, N. 2020. Dampak Pandemi Covid-19 Terhadap Kegiatan Belajar Mengajar Di Indonesia. Jurnal Psikologi Volume 13 No.2, Desember 2020

https://covid19.go.id/. Diakses 25 Juni 2021 jam 13.

Hidayah, N. (2020). Efektifitas Blended Learning Dalam Proses Pembelajaran. Pencerahan, 14(1), 1-15. Retrieved from http://www.jurnalpencerahan.org/index .php/jp/article/view/41

Istiqomah, S. (2013). Penerapan Metode Blended Learning Berbasis Ict Untuk Meningkatkan Minat Dan Prestasi Belajar Pada Mata Kuliah Ilmu Sosial Budaya Dasar (Isbd) Di Prodi D-Iii Kebidanan Fik Unipdu Jombang. Jurnal EduHealth, 3(2), 245718.

Nomor, V., Dosen, B., \& Saat, K. (2021). Jurnal Peduli Masyarakat. 3(September), 199-206.

PRAPITASARI, R. (2020). Pembelajaran Daring Partograf Pada Mata Kuliah Asuhan Kebidanan Persalinan Masa Pandemi. Jurnal Ekonomi, Sosial \& ..., 02(02), 123-128. Retrieved from https://www.jurnalintelektiva.com/inde x.php/jurnal/article/view/424

Suharsimi Arikunto. Dasar-Dasar Evaluasi Pendidikan. Jakarta. Bumi Aksara. 2012

Rudiansyah, R, Permana, R. Feladi, V. 2019.Pembelajaran Blended Learning Terhadap Hasil Belajar Siswa. Jurnal Pendidikan Teknologi Informasi dan 
Komputer (JPTIK) ISSN 2716-1730.

Vol.1. No.1(2019)

Syswianti, D., Suryani, N., \& Wahyuni, T.

(2020). Evaluasi Pembelajaran Daring

Dengan Menggunakan Aplikasi Zoom di

Masa Pendemi Covid-19 Pada Mata

Kuliah Pengantar Asuhan

Kebidanan. Jurnal Medika

Cendikia, 7(1), 40-50.

https://doi.org/10.33482/medika.v7i1.129 